\title{
The Effect of Endoprosthesis Selection on Functional Outcomes in the Elderly with Femoral Neck Fractures
}

\author{
Femoral Boyun Kırığı Olan Yaşlılarda Endoprotez Seçiminin Fonksiyonel \\ Sonuçlar Üzerine Etkisi
}

(D) Hasan May, (D) Yusuf Alper Katı

Antalya Training and Research Hospital, Clinic of Orthopedics and Traumatology, Antalya, Turkey

\section{Abstract}

Objective: Hemiarthroplasty is the most common treatment for femoral neck fractures in patients aged $\geq 60$ years. In this study, we aimed to compare the functional outcomes of unipolar and bipolar endoprostheses used in hemiarthroplasty in the elderly with femoral neck fractures.

Method: A total of 63 patients aged $\geq 60$ years, who underwent hemiarthroplasty for femoral neck fractures between 2004 and 2019, were included. A unipolar and bipolar endoprosthesis was applied to 36 and 27 patients, respectively. All patients were followed for minimum 12 months. The fractures were assessed using the Pauwels classification. Demographic and clinical characteristics of the patients were recorded. Postoperative hip function was evaluated using the Harris hip score (HHS).

Results: The mean age was $74.1 \pm 7.3$ years in the unipolar endoprosthesis group and $72.9 \pm 8.3$ years in the bipolar endoprosthesis group. There was no significant difference in the age, sex, and localization of the fracture between the groups. A significant difference in the fracture types according to the Pauwels classification was observed between the two endoprosthesis groups $(p<0.01)$. Follow-up duration, dislocation, reoperation, and wound infection were similar between the groups. The mean limp, ability of putting on socks, mobility, and ability of using public transportation subscale scores of the HHS were significantly higher in the patients undergoing bipolar arthroplasty $(p=0.014, p=0.020, p=0.026$, and $p=0.03$, respectively). However, the total HHS was comparable between the groups $(p=0.728)$.

Conclusion: Our study results show that bipolar arthroplasty yields more favorable results in patients with a better predictable mobilization based on the HSS subscale scores. Of note, unipolar arthroplasty is a more lowcost treatment method in the elderly patients with femoral neck fractures.

Keywords: Femoral neck fracture, Harris hip score, hemiarthroplasty

\section{Öz}

Amaç: Hemiartroplasti, $\geq 60$ yaş hastalarda femur boyun kırıklarının tedavisinde en sık kullanılan tedavidir. Bu çalışmada, femur boyun kırıklı yaşı hastalarda hemiartroplastide kullanılan unipolar ve bipolar endoprotezlerin fonksiyonel sonuçları karşılaştıııldı.

Yöntem: Bu çalışmaya 2004-2019 yılları arasında femur boyun kırığı nedeniyle hemiartroplasti yapılan $\geq 60$ yaş üzeri toplam 63 hasta alındı. Hastaların 36'sına unipolar, 27'sine ise bipolar endoprotez takıldı. Tüm hastalar en az 12 ay süreyle takip edildi. Kırıklar Pauwels sınıflandırmasına göre değerlendirildi. Hastaların demografik ve klinik özellikleri kaydedildi. Ameliyat sonrası kalça fonksiyonları, Harris kalça skoru (HHS) ile değerlendirildi.

Bulgular: Unipolar endoprotez implante edilen grubun ortalama yaşı $74,1 \pm 7,3$ yıl, bipolar endoprotez takılan grubun ortalama yaşı $72,9 \pm 8,3$ yı idi. Gruplar arasında yaş, cinsiyet ve kırık lokalizasyonu açısından anlamlı bir fark izlenmedi. Pauwels sınıflandırmasına göre kırık tipleri açısından iki endoprotez grubu arasında anlamlı bir fark vardı $(p<0,01)$. Takip süresi, dislokasyon ve yara yeri enfeksiyonu gruplar arasında benzerdi. HHS'nin ortalama topallama, çorap giyme, hareket kabiliyeti ve toplu taşıma aracına binme alt başlıklarının ortalama skoru, bipolar artroplasti uygulanan hastalarda anlamlı düzeyde daha yüksekti (sırasıyla; $p=0,014$, $p=0,020, p=0,026$, ve $p=0,03)$. Ancak toplam HHS skoru, gruplar arasında benzerdi $(p=0,728)$.

Sonuç: Çalışma sonuçlarımız HSS alt başlık skorlarına göre mobilizasyonun daha iyi öngörülebildiği hastalarda bipolar artroplastinin daha iyi sonuçlar verdiğini göstermektedir. Bununla birlikte unipolar artroplasti, femur boyun kırığı olan yaşlı hastalarda daha düşük maliyetli bir tedavi yöntemidir.

Anahtar kelimeler: Femur boyun kırı̆ı̆ı, Harris kalça skoru, hemiartroplasti

Address for Correspondence: Yusuf Alper Katı, Antalya Training and Research Hospital, Clinic of Orthopedics and Traumatology, Antalya, Turkey E-mail: alperkati@gmail.com ORCID: orcid.org/0000-0003-2706-3813 Received: 12.03.2021 Accepted: 11.06.2021

Cite this article as: May H, Katı YA. The Effect of Endoprosthesis Selection on Functional Outcomes in the Elderly with Femoral Neck Fractures. Bagcilar Med Bull 2021;6(3):242-247

๑) Copyright 2021 by the Health Sciences University Turkey, Bagcilar Training and Research Hospital Bagcilar Medical Bulletin published by Galenos Publishing House. 


\section{Introduction}

Hip fractures are debilitating conditions which make patients dependent on a constant care due to reduced mobilization and are associated with high morbidity and mortality rates in the elderly (1). With the aging population and high incidence of osteoporosis, these fractures remain an important public health issue $(1,2)$. According to the Swedish National Hip Fracture Registry, also called RIKSHÖFT, femoral neck fractures account for nearly half of all hip fractures and two-thirds of them are displaced fractures (3). In addition, the majority of displaced hip fractures require surgical treatment with a high cost burden on the healthcare system.

The main goals of surgical treatment are to relieve pain promptly, to enable early mobilization and rehabilitation, and to minimize procedure-related complications (4). Although the most optimal treatment of femoral neck fractures has been a long debate, there are two main methods used in the treatment: internal fixation and arthroplasty. In principle, internal fixation enables the reduction of the fracture and prevents displacement. However, this procedure is associated with several complications such as non-union and avascular necrosis in the elderly, leading to reduced function and increased morbidity (5). Arthroplasty is a surgical procedure in which the prosthetic replacement of the femoral head and neck is performed and is helpful to prevent complications related to internal fixation that makes arthroplasty a feasible alternative, particularly in the elderly (6). Nevertheless, there is no consensus on the optimal treatment of displaced intracapsular fractures in patients aged $\geq 60$ years ( 7 ).

The selection of unipolar versus bipolar endoprostheses is still a matter of debate for the treatment of displaced femoral neck fractures in the elderly. Theoretically, bipolar prostheses have certain advantages, as they are specifically designed to enable motion at its inner bearing in addition to the prosthesis-acetabulum interface, thereby, decreasing the amount of acetabular erosion and reducing pain (2). However, some authors have advocated reduced inner bearing mobility over time and that these prostheses act similarly to the unipolar ones $(8,9)$. In addition, unipolar prostheses are more cost-effective than the bipolar prostheses and are easy-to-apply during surgery (9).

In the literature, there are randomized-controlled studies showing that bipolar hemiarthroplasty is more advantageous than the unipolar hemiarthroplasty, while some others have found no significant difference, leading to inconsistent results $(8,10)$. In the present study, we aimed to compare the functional outcomes of unipolar and bipolar endoprostheses used in hemiarthroplasty in the elderly with femoral neck fractures.

\section{Materials and Methods}

\section{Study Design and Study Population}

This double-centered, retrospective study was conducted at Dr. Muhittin Ülker First Aid Training and Research Hospital and Antalya Training and Research Hospital between January 2004 and December 2019.

A total of 63 patients aged $\geq 60$ years, who underwent hemiarthroplasty for isolated and displaced femoral neck fractures and were followed for minimum 12 months, were included in the study. Patients who were surgically treated with the methods other than unipolar or bipolar endoprostheses were excluded from the study. Those having pathological fractures and multiple fractures, requiring additional surgical treatment, and having missing followup data were also excluded. Since functional evaluation was aimed in the study, patients who died during the follow-up were also excluded from the study. The patients were divided into two groups as those receiving a unipolar endoprosthesis $(n=36)$ and those receiving a bipolar endoprosthesis $(n=27)$. The fractures were assessed using the Pauwels classification. Demographic and clinical characteristics of the patients including age, sex, fracture type, complications and procedure-related complications (i.e., wound infection, dislocation or reoperation) were obtained from the hospital records. Postoperative functional outcomes were evaluated based on the phone calls to patients and/or their relatives. Postoperative hip function was evaluated using the Harris Hip Score (HHS) at the $12^{\text {th }}$ month.

\section{Surgical Procedure}

The surgery was performed in the lateral decubitus position using a posterior incision by a single surgeon. All patients were administered prophylactic antibiotherapy and prophylactic treatment for venous thromboembolism. In the postoperative period, early mobilization and full weight bearing were allowed depending on each individual patient. Mobilization was maintained in all patients during the hospital stay and the patients were discharged with home-based exercises. Following surgery, the patients were scheduled for follow-up in the outpatient setting and the functional outcomes were evaluated using the HHS. 


\section{Statistical Analysis}

Statistical analysis was performed using the SPSS version 17.0 software (SPSS Inc., Chicago, IL, USA). The normality assumption was checked using the Shapiro-Wilk test. Descriptive data were expressed in mean \pm standard deviation or median (minimum-maximum) for continuous variables and in number and frequency for categorical variables. The mean differences in ages and follow-up duration between the unipolar and bipolar groups were compared using the Student's t-test, while the MannWhitney $U$ test was performed for the comparison of the scores of HSS. Categorical data were analyzed using the Pearson's chi-square $\left(\chi^{2}\right)$ or Fisher-Freeman-Halton test, where applicable. A p-value of $<0.05$ was considered statistically significant.

\section{Results}

Of all patients, 26 were males and 37 were females with a mean age of $73.57 \pm 7.8$ (range, $60-90$ ) years. Of the unipolar prosthesis group, 15 were male and 21 were female with a mean age of $74.1 \pm 7.3$ years. Of the bipolar prosthesis group, 11 were male and 16 were female with a mean age of $72.9 \pm 8.3$ years, indicating no statistically significant difference between the groups $(\mathrm{p}=0.941)$. The mean follow-up was $31.4 \pm 10.0$ months and $36.0 \pm 12.8$ months in the unipolar and bipolar prosthesis groups, respectively, indicating no statistically significant difference between the groups ( $\mathrm{p}=0.111$ ) (Table 1 ).

According to the Pauwels classification, seven (19.4\%) patients had type I, 17 (47.2\%) patients had type II, and $12(33.3 \%)$ patients had type III fractures in the unipolar prosthesis group. All cases were displaced femur neck fracture. These figures were one $(3.7 \%)$, five $(18.5 \%)$, and $21(77.8 \%)$ patients, respectively, in the bipolar prosthesis group. The number of type I ( $\mathrm{n}=7$ vs. $\mathrm{n}=1$, respectively, $\mathrm{p}<0.001$ ) and type II fractures ( $\mathrm{n}=17$ vs. $\mathrm{n}=5$, respectively, $\mathrm{p}<0.001$ ) was significantly higher in the unipolar prosthesis group, while the number of type III fractures was significantly higher in the bipolar prosthesis group $(n=21$ vs. $\mathrm{n}=12$, respectively, $\mathrm{p}<0.001$ ) (Figure 1 ). Of the unipolar prosthesis group, 18 had right femoral neck fractures and 18 had left femoral neck fractures. Of the bipolar prosthesis group, 12 had right femoral neck fractures and 15 had left femoral neck fractures, which indicated no statistically significant difference $(\mathrm{p}=0.662)$ (Table 1$)$.

According to the postoperative complications affecting the functional outcomes, four patients had postoperative dislocation in the unipolar prosthesis group, while reoperation was needed in only one of these patients. In the

\begin{tabular}{llll}
$\begin{array}{l}\text { Table 1. Demographic and clinical characteristics of patient } \\
\text { groups }\end{array}$ & $\begin{array}{l}\text { Unipolar } \\
\text { Variable }\end{array}$ & $\begin{array}{l}\text { Bipolar } \\
(\mathbf{n = 2 7})\end{array}$ & $\mathbf{p}$ \\
\hline Age (year) & $74.1 \pm 7.3$ & $72.9 \pm 8.3$ & $0.548^{\dagger}$ \\
Sex & - & - & $0.941^{\ddagger}$ \\
Female & $21(58.3 \%)$ & $16(59.3 \%)$ & - \\
Male & $15(41.7 \%)$ & $11(40.7 \%)$ & - \\
Localization & - & - & $0.662^{\ddagger}$ \\
Right & $18(50.0 \%)$ & $12(44.4 \%)$ & - \\
Left & $18(50.0 \%)$ & $15(55.6 \%)$ & - \\
Pauwels & - & - & $<0.001^{4}$ \\
classification & & $1(3.7 \%)$ & - \\
I & $7(19.4 \%)$ & $5(18.5 \%)$ & - \\
II & $17(47.2 \%)$ & $21(77.8 \%)$ & - \\
III & $12(33.3 \%)$ & $36.0 \pm 12.8$ & $0.111^{\dagger}$ \\
Follow-up (months) & $31.4 \pm 10.0$ & $3(11.1 \%)$ & $>0.991^{\S}$ \\
Dislocation/ & $4(11.1 \%)$ & $3(11.1 \%)$ & $>0.892^{\S}$ \\
reoperation & & $5(13.9 \%)$ & \\
Wound infection & & & \\
\hline
\end{tabular}

'Student's t-test, $¥$ Pearson chi-square test, "Fisher-Freeman-Halton test, ${ }^{\S}$ Fisher's Exact test. Data are given in mean \pm standard deviation or number and frequency, unless otherwise stated

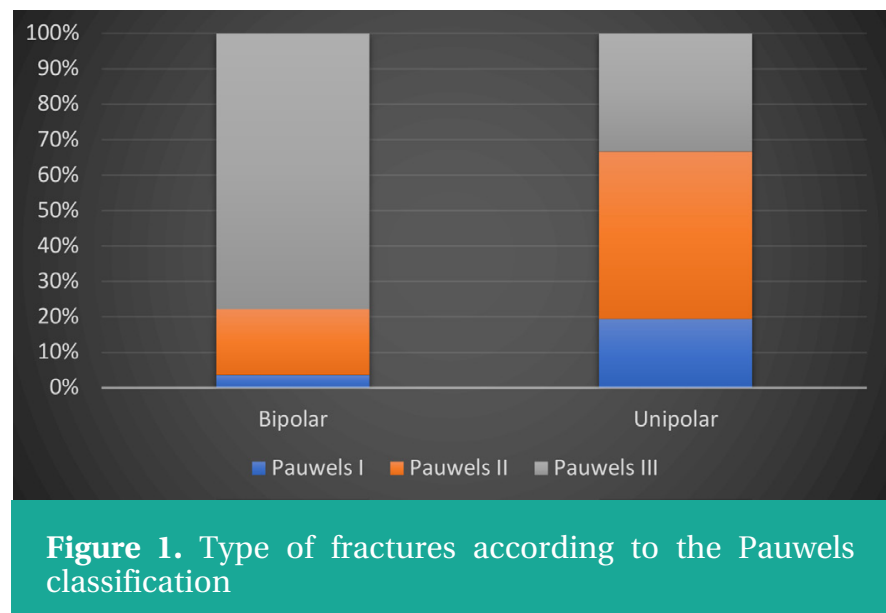

bipolar prosthesis group, three patients had postoperative dislocation and one of them required reoperation. There was no significant difference in the development of hip dislocation and need for reoperation between the groups ( $p=0.991$ ). In addition, four patients experienced superficial infection, while one patient had deep infection in the unipolar prosthesis group. In the bipolar prosthesis group, two patients had superficial infection and one patient had deep infection, indicating no significant difference between the groups ( $\mathrm{p}=0.892)$. Surgical debridement was performed in only one of the patients having infection $(n=1$, bipolar prosthesis group), while the remaining patients were treated with antibiotherapy. 
Table 2. Total Harris hip scores and subscale scores of patient groups

\begin{tabular}{|c|c|c|c|}
\hline & $\begin{array}{l}\text { Unipolar } \\
(n=36)\end{array}$ & $\begin{array}{l}\text { Bipolar } \\
(n=27)\end{array}$ & $\mathbf{p}^{\dagger}$ \\
\hline Pain & $41.72 \pm 4.66$ & $41.11 \pm 4.41$ & 0.455 \\
\hline Limp & $8.58 \pm 1.73$ & $9.67 \pm 1.73$ & $0.014 *$ \\
\hline Support & $6.97 \pm 3.14$ & $5.96 \pm 2.71$ & 0.296 \\
\hline Distance & $6.67 \pm 3.62$ & $7.00 \pm 2.76$ & 0.768 \\
\hline Climbing stairs & $2.00 \pm 1.12$ & $1.59 \pm 1.28$ & 0.099 \\
\hline $\begin{array}{l}\text { Putting on shoes and } \\
\text { socks }\end{array}$ & $2.61 \pm 1.25$ & $3.33 \pm 0.96$ & $0.020 *$ \\
\hline Sitting & $4.78 \pm 0.64$ & $5.00 \pm 0.00$ & 0.076 \\
\hline $\begin{array}{l}\text { Using public } \\
\text { transportation }\end{array}$ & $0.69 \pm 0.47$ & $0.93 \pm 0.27$ & $0.026 *$ \\
\hline Deformity & $3.94 \pm 0.33$ & $4.00 \pm 0.00$ & 0.386 \\
\hline Mobility & $4.14 \pm 0.80$ & $4.67 \pm 0.68$ & $0.003^{*}$ \\
\hline Total & $82.11 \pm 12.33$ & $83.26 \pm 10.84$ & 0.728 \\
\hline
\end{tabular}



Figure 2. Functional outcomes according to the Harris hip scores

Functional outcomes were evaluated using the HHS following surgery. There was no significant difference in the mean and total subscale scores of the HHS including pain, amount and type of support used, limp, distance that could be walked, climbing stairs, and deformity between the unipolar and bipolar prosthesis groups ( $p>0.05$ ). However, the mean limp, ability of putting on socks, mobility, and ability of using public transportation subscale scores of the HHS were significantly higher in the patients undergoing bipolar arthroplasty $(\mathrm{p}=0.014, \mathrm{p}=0.020, \mathrm{p}=0.026$, and $\mathrm{p}=0.03$, respectively) (Table 2) (Figure 2).

\section{Discussion}

Due to the aging population, femoral neck fractures have become an increasingly serious public health problem in the elderly and a growing burden on global healthcare systems in recent years (11). With the increasing rate of osteoporosis and non-union complications in this group of patients, novel surgical procedures which allow early mobilization have been widely adopted. In the literature, hemiarthroplasty is recommended as an effective treatment modality for femoral neck fractures, particularly in patients aged $\geq 60$ years (11-15) .

There is a variety of prosthetic types and designs used in hemiarthroplasty. Unipolar prostheses have a one-piece design where the hip movement occurs between the prosthesis and the acetabulum, while bipolar prostheses have an additional artificial joint between the two components of the prosthesis. In addition, the bipolar head offers a second articulation between an inner smaller head and the polyethylene liner of the larger outer head (11). Both treatment methods are clinically proven and certain merits and demerits. To illustrate, unipolar prostheses are cost-effective and associated with a lower rate of hip dislocation and improved stability (15). However, acetabular erosion with the use of a monoblock prosthetic design is a well-documented complication (13). Although bipolar prostheses result in less acetabular erosion thanks to their dual-articulation design, the implementation of these prostheses is more difficult than the unipolar ones $(11,13,16)$.

In the present study, we observed no significant difference in the age, sex, location of the fractures, and functional outcomes between the unipolar and bipolar prosthesis groups. In advanced age, unipolar prostheses are more commonly preferred, owing to the relatively low dislocation incidence, easy-to-use design in a timely manner, and cost-efficacy $(15,17)$. The cost is an important variable for these patients. Advanced age has been shown to be associated with poor functional outcomes (17). However, poor functional outcomes have not been fully proven to be linked to advanced age or prosthetic material used $(13,16)$. Although studies investigating the effect of sex on hip fracture have demonstrated a relationship between the male sex and the increased mortality $(9,18)$, no significant effect of sex on functional outcomes has been shown $(13,16)$.

Procedure-related complications such as dislocation and need for reoperation impair the quality of life of patients and increase the mortality and health expenditures (19). In our study, all surgeries were performed using a single surgical technique with a posterior incision. This technique poses a higher risk for dislocation than the anterolateral approach (20). In this study, we observed no significant difference 
in the rate of dislocation and reoperation between the unipolar and bipolar prosthesis groups. According to the RIKSHÖFT, which contains data on more than 300,000 hip fractures since the late 1980s, bipolar implants have a lower risk of reoperation than the unipolar implants, irrespective of dislocations or periprosthetic fractures (21). However, recent metaanalyses revealed that the rate of dislocation and reoperation was comparable between the unipolar and bipolar prostheses, consistent with our study findings $(14,22)$. Additionally, in the current study, the rate of superficial and deep wound infections was similar between the two prosthesis groups, which is consistent with the literature (12).

Although the functional outcomes can be evaluated using specific tools such as the Western Ontatio and McMaster University, osteoarthritis index, short form36 , and health-related quality of life, the HHR is the most widely used outcome measure for the assessment of hip fractures, particularly of the hip function before and after hip arthroplasties (14). Similarly, we used the HHS for the evaluation of postoperative functional outcomes in our study. Theoretically, bipolar prostheses seem to be more advantageous than the unipolar implants thanks to their motion at the inner bearing and prosthesis-acetabulum interface, resulting in less acetabular erosion. In this context, some authors reported similar functional outcomes with these two prostheses, while some others suggested that bipolar hemiarthroplasty was associated with more favorable functional outcomes $(13,17)$. In our study, the total HHS was comparable between the two prosthesis groups, consistent with the previous studies. However, the mean limp, ability of putting on socks, mobility, and ability of using public transportation subscale scores of the HHS were significantly higher in the patients undergoing bipolar arthroplasty. Similarly, in their study, De los Santos et al. (23) found no significant difference in the total HSS between the unipolar and bipolar prosthesis groups, although the ability of walking and support (i.e., using canes) subscale scores significantly improved in the patients undergoing surgery with bipolar prosthesis. The discrepancy between the studies was attributed to the age of the patients included in the studies (i.e., younger ones were included in some of the studies) and already better functional scores before the development of fractures $(23,24)$. In our study, however, we found a significant difference in the HHS subscale scores which cannot be explained by the age of the patients, as the mean age was similar between the groups. Indeed, the three subscales of HHS (the ability of putting on socks, mobility, and ability of using public transportation) measure the joint range of motion. This finding, therefore, indicates that bipolar arthroplasty can offer a more favorable joint range of motion.

Total hip arthroplasty is another option that can be applied in femoral neck fractures. It can be a good alternative to hemiarthroplasty, especially in patients with a good general condition and high functional capacity (25). Considering data about the two methods, it is seen that total hip arthroplasty has a better effect and function in treatment. However, long operation time and postoperative recovery time are a disadvantage for THA treatment. On the contrary, patients undergoing hemiarthroplasty have shorter operation time and faster recovery. These two conditions constitute very important advantages for the elderly patients. Therefore, the choice of adopting treatment plan in clinical practices should be made by combining the conditions of the patients with the advantages of the treatment measures (26).

\section{Study Limitations}

Nonetheless, there are some limitations to this study. First, the study design is retrospective with a relatively small sample size, indicating a low level of evidence. Second, we were unable to compare pre- and postoperative functional scores of the patients and, thus, independent factors affecting the surgical success may have had an effect on the functional outcomes. However, demographic characteristics of the patients are highly homogeneous. Finally, although there are similar studies on this research topic in the literature, the ideal choice for partial arthroplasty is still controversial.

\section{Conclusion}

Unipolar and bipolar arthroplasty are widely used in the treatment of femoral neck fractures in patients aged $\geq 60$ years. Based on our study results, we recommend bipolar prostheses for patients requiring early mobilization, while similar results can be achieved with unipolar prostheses which are more cost-effective alternatives.

\section{Ethics}

Ethics Committee Approval: This study was approved by the Antalya Training and Research Hospital, Ethics Committee with the approval no. 2020-228 and date: $23 / 07 / 2020$.

Informed Consent: A written informed consent was obtained from all patients. 
Peer-review: Externally peer-reviewed.

\section{Authorship Contributions}

Concept: H.M., Y.A.K., Design: H.M., Y.A.K., Data Collection or Processing: H.M., Y.A.K., Analysis or Interpretation: H.M., Y.A.K., Writing: H.M., Y.A.K.

Conflict of Interest: No conflict of interest was declared by the authors.

Financial Disclosure: The author declared that this study has received no financial support.

\section{References}

1. Giannoudis PV, Kontakis G, Christoforakis Z, Akula M, Tosounidis T, Koutras C. Management, complications and clinical results of femoral head fractures. Injury 2009;40(12):1245-1251.

2. Sterling RS. Gender and race/ethnicity differences in hip fracture incidence, morbidity, mortality, and function. Clin Orthop Relat Res 2011;469(7):1913-1918.

3. Thorngren KG, Hommel A, Norrman PO, Thorngren J, Wingstrand H. Epidemiology of femoral neck fractures. Injury 2002;33(3):1-7.

4. Lowe JA, Crist BD, Bhandari M, Ferguson TA. Optimal treatment of femoral neck fractures according to patient's physiologic age: an evidence-based review. Orthop Clin North Am 2010;41(2):157-166.

5. Lu-Yao GL, Keller RB, Littenberg B, Wennberg JE. Outcomes after displaced fractures of the femoral neck. A meta-analysis of one hundred and six published reports. J Bone Joint Surg Am 1994;76(1):15-25.

6. Van Vugt AB. The unsolved fracture. A prospective study of 224 consecutive cases with an intracapsular hip fracture. Thesis, University of Nijmegen, Nijmegen: 1991.

7. Nicoll EA. The unsolved fracture. J Bone Joint Surg $\mathrm{Br}$ 1963;45(2):239-241.

8. Inngul C, Hedbeck CJ, Blomfeldt R, Lapidus G, Ponzer S, Enocson A. Unipolar hemiarthroplasty versus bipolar hemiarthroplasty in patients with displaced femoral-neck fractures: A four-year followup of a randomised controlled trial. Int Orthop 2013;37(12):24572464.

9. Ong BC, Maurer SG, Aharonoff GB, Zuckerman JD, Koval KJ. Unipolar versus bipolar hemiarthroplasty: functional outcome after femoral neck fracture at a minimum of 36 months of followup. J Orthop Trauma 2002;16(5):317-322.

10. Calder SJ, Anderson GH, Jagger C, Harper WM, Gregg PJ. Unipolar or bipolar prosthesis for displaced intracapsular hip fracture in octogenarians: A randomised prospective study. J Bone Joint Surg Br 1996;78(3):391-394.

11. Zhou Z, Yan F, Sha W, Wang L, Zhang X. Unipolar versus bipolar hemiarthroplasty for displaced femoral neck fractures in elderly patients. Orthopedics 2015;38(11):697-702.
12. Somashekar, Krishna SV, Sridhara Murthy J. Treatment of femoral neck fractures: unipolar versus bipolar hemiarthroplasty. Malays Orthop J 2013;7(2):6-11.

13. Filippo M, Driessen A, Colarossi G, Quack V, Tingart M, Eschweiler J. Bipolar versus monopolar hemiarthroplasty for displaced femur neck fractures: A meta-analysis study. Eur J Orthop Surg Traumatol 2020;30(3):401-410.

14. Yang B, Lin X, Yin XM, Wen XZ. Bipolar versus unipolar hemiarthroplasty for displaced femoral neck fractures in the elder patient: A systematic review and meta-analysis of randomized trials. Eur J Orthop Surg Traumatol 2015;25(3):425-433.

15. Jia Z, Ding F, Wu Y, Li W, Li H, Wang D, et al. Unipolar versus bipolar hemiarthroplasty for displaced femoral neck fractures: a systematic review and meta-analysis of randomized controlled trials. J Orthop Surg Res 2015;10:8.

16. Emirhan N, Albayrak A, Çamurcu İ, Üçpunar H, Yapıcı F, Çöbden A. Comparison of mortality after cemented and cementless hemiarthroplasty for the treatment of femoral neck fracture in patients aged over 65 years old mortality after hemiarthroplasty. Bozok Tip Dergisi 2020;10(2):177-183.

17. Bölük $K$, Bilgen $M$, Durak K. İleri yaş ayrılmıș femur boyun kırıklarında unipolar ve bipolar protez uygulamaları. Uludağ Üniversitesi Tıp Fakültesi Dergisi 2008;34(2):41-44.

18. Magaziner J, Simonsick EM, Kashner TM, Hebel JR, Kenzora JE. Survival experience of aged hip fracture patients. Am J Public Health 1989;79(3):274-278.

19. Blewitt N, Mortimore S. Outcome of dislocation after hemiarthroplasty for fractured neck of the femur. Injury 1992;23(5):320-322.

20. Woo RY, Morrey BF. Dislocations after total hip arthroplasty. J Bone Joint Surg Am 1982;64(9):1295-306.

21. Leonardsson O, Kärrholm J, Åkesson K, Garellick G, Rogmark C. Higher risk of reoperation for bipolar and uncemented hemiarthroplasty. Acta Orthop 2012;83(5):459-466.

22. Enocson A, Hedbeck CJ, Törnkvist H, Tidermark J, Lapidus LJ. Unipolar versus bipolar Exeter hip hemiarthroplasty: a prospective cohort study on 830 consecutive hips in patients with femoral neck fractures. Int Orthop 2012;36(4):711-717.

23. De los Santos R, Cordero-Ampuero J, Rodriguez- Salvanés F, González R. Comparison of radiological acetabular erosion between hemiarthroplasties: cemented Thompson unipolar vs. uncemented HAP Furlong bipolar. Eur Orthop Traumatol 2012;3(2):115-120.

24. Parker MJ, Gurusamy KS, Azegami S. Arthroplasties (with and without bone cement) for proximal femoral fractures in adults. Cochrane Database Syst Rev 2010;(6):CD001706. doi: 10.1002/14651858.CD001706.pub4

25. Wei X, Hao L. Study of curative effect of cemented hemiarthroplasty and total hip replacement in treatment of elderly patients with femoral neck fracture. Med Health Care 2014;22:46.

26. Ren C, Guo J, Gao Y. Comparison of total hip arthroplasty and hemiarthroplasty in elderly patients with femoral neck fracture. Biomed Res 2017;28(16):7127-7130. 